\title{
The development of intergroup bias in childhood: How social norms can shape children's racial behaviours
}

\section{Maria Benedicta Monteiro}

ISCTE, Department of Social and Organizational Psychology, and Research Centre for Social

Research and Intervention, Lisboa, Portugal

\author{
Dalila Xavier de França
}

Universidade Federal de Sergipe, Aracajú, Brasil

\section{Ricardo Rodrigues}

ISCTE, Department of Social and Organizational Psychology, and Research Centre for Social Research and Intervention, Lisboa, Portugal

\begin{abstract}
$T$ he present research examined the developmental course of racial behaviours in childhood. It tested the hypothesis that White children's expressions of racial prejudice do not necessarily decline in middle childhood due to the development of particular cognitive skills but that instead, as argued by the socio-normative approach, children older than seven will go on expressing prejudiced attitudes under appropriate conditions. This would be explained by the presence of an anti-racism norm, along with the existence of values promoting equal rights, which impede blatant expressions of racism. In the first study 283 White children aged 6-7 and 9-10 years performed a task of resource allocation to White and Black target children in conditions of high (White interviewer was present) or low (White interviewer was absent) salience of the anti-racist norm. The 6- to 7-yearold children discriminated against the Black target in both conditions whereas older children discriminated against the Black child only when the anti-racist norm was not salient. In Study 2, 187 White children aged 6-7 and 9-10 years performed the same resource allocation task in conditions of explicit activation of similarity vs dissimilarity or egalitarian vs merit-based norms regarding race relations. Supporting the hypothesis of the role of racist or anti-racist norms on the expression of intergroup discrimination, results have again shown that 6- to 7year-old children discriminated against the Black target in both conditions while older children presented significantly different prejudiced/nonprejudiced behaviours consistent with the activated norms. These results were discussed in terms of the need for a reanalysis of the assumptions and research results of the cognitivedevelopmental theory and of further developments in the socio-normative approach regarding the development of prejudice in childhood.
\end{abstract}

I a présente recherche a examiné le cours du développement des comportements raciaux pendant l'enfance. $\mathcal{L}$ L'étude a testé l'hypothèse que les expressions de préjugés raciaux des enfants blancs ne diminuent pas nécessairement au milieu de l'enfance à cause du développement d'habiletés cognitives particulières mais plutôt, tel qu'avancé par l'approche socio-normative, sous des conditions appropriées, les enfants de plus de 7 ans continueront à exprimer des préjugés. Ceci serait expliqué par la présence d'une norme anti-raciste ainsi que l'existence de valeurs qui promouvoient les droits égaux, ce qui empêche les expressions flagrantes de racisme. Dans la première étude, 283 enfants blancs âgés de 6-7 et de 9-10 ans ont accompli une tâche d'allocation de ressources à des enfants-cibles blancs et noirs dans des conditions de saillance élevée (un interviewer blanc était présent) ou faible (un interviewer blanc était absent) de la norme anti-raciste. Les enfants de 6-7 ans ont

Correspondence should be addressed to Maria Benedicta Monteiro, Department of Social and Organizational Psychology, ISCTE, University Institute of Lisbon, Av. Forças Armadas, Edif. ISCTE, 1649-026, Lisboa, Portugal (E-mail: mbbm@iscte.pt).

This article was supported by two research grants awarded to the first and third authors (POCTI/PSI/41970/2001 and SFRH/BD/ 16834/2004) by the Portuguese Foundation for Science and Technology and by a grant from CAPES, Brazil, awarded to the second author. The authors are very grateful to Claudia Dalbert (IJP Editor-in-Chief), Jorge Vala (IJP Consulting Editor), Rodrigo Brito, and three anonymous reviewers for their helpful comments on a previous version of this paper. Much appreciation is extended to the teachers and children for their participation.

(C) 2008 International Union of Psychological Science 
discriminé contre la cible noire dans les deux conditions alors que les enfants plus âgés ont discriminé contre l'enfant noir seulement lorsque la norme anti-raciste n'était pas saillante. Dans la deuxième étude, 187 enfants blancs âgés de 6-7 ans et de 9-10 ans ont accompli la même tâche d'allocation de ressources dans des conditions d'activation explicite de similarité $v s$ dissimilarité ou égalitaire $v s$ normes basées sur le mérite en ce qui concerne les relations inter-raciales. En appuyant l'hypothèse du rôle des normes racistes ou anti-racistes dans l'expression de la discrimination inter-groupe, encore une fois les résultats ont indiqué que les enfants âgés de 6-7 ans ont discriminé contre la cible noire dans les deux conditions alors que les enfants plus âgés ont présenté des préjugés/ des non-préjugés en accord avec les normes activées. Ces résultats ont été discutés en termes du besoin d'une reanalyse des hypothèses de base et des résultats de recherche de la théorie cognitivo-développementale et, aussi, en termes de plus de développements de l'approche socio-normative en ce qui concerne le développement des préjugés pendant l'enfance.

L presente estudio investiga el proceso de desarrollo de conductas racistas en la infancia. Se examinó la
hipótesis de que las expresiones de prejuicio racial en niños de raza blanca no disminuyen necesariamente
durante la niñez media debido al desarrollo de habilidades cognitivas específicas, sino más bien como argumenta
la aproximación socio-normativa, bajo determinadas condiciones, niños por encima de los siete años continuarán
presentando actitudes de prejuicio. Esto se puede explicar a través de la existencia de una norma antiracista, así
como debido a la existencia de valores que promueven la igualdad de derechos, los cuales impiden una expresión
abierta de racismo. En el primer estudio 283 niños de raza blanca entre 6-7 y 9-10 años de edad desarrollaron
una tarea de adjudicación de recursos en niños de raza blanca y negra en condiciones de alta (entrevistador
blanco estuvo presente) y baja saliencia (entrevistador blanco estuvo ausente) de la norma antiracista. Mientras
los niños entre $6-7$ años discriminaron a los niños de raza negra en ambas condiciones, los niños de mayor edad
discriminaron a los niños de raza negra sólo cuando la norma antiracista no fue activada. En un segundo estudio
completaron 187 niños de raza blanca entre 6-7 y 9-10 años de edad la misma tarea de adjudicación de recursos
en condiciones de activación explícita de similitud vs. diferencia o igualdad vs. normas basadas en el mérito
respecto de relaciones raciales. La hipótesis del rol de normas racistas y antiracistas en la expresión de
discriminación intergrupal fue confirmada. Los resultados mostraron nuevamente que niños entre 6-7 años de
edad discriminaron a niños de raza negra en ambas condiciones, mientras que los niños mayores mostraron una
diferencia significativa respecto de las conductas prejuiciosas/no prejuiciosas que eran consecuentes con las
normas activadoras. Estos resultados se discutieron en término de las necesidades de un reanálisis de las
suposiciones teóricas y de los resultados de la investigación en el campo de la teoría del desarrollo cognitivo, así
como de las nuevas posiciones de la aproximación socio-normativa respecto del desarrollo de prejuicio en la
infancia. Keywords: Child development; Intergroup bias; Normative control; Racial discrimination; Social norms.

Research over the past 20 years shows that expressions of racism toward disadvantaged ethnic minorities by White persons have become more indirect. This adjustment seems to be related to the presence of an anti-racist norm, along with the existence of values promoting equal rights, which repress blatant expressions of racism (Gaertner \& Dovidio, 1986; Pettigrew \& Meertens, 1995). Research has also found that consequences of racial prejudice did not significantly decrease as discrimination maintains the same pervasive and negative effects (Dovidio, Kawakami, \& Beach, 2001). Most of these studies have been undertaken with adults and only recently have a few analysed the effects of anti-racist norms on children's prejudiced behaviours. This limitation can largely be due to the general idea in the mainstream social development literature that intergroup bias in early childhood is related more to limitations in children's cognitive capacities than to the learning and internalization of social norms (Aboud, 1988).

The cognitive-developmental theory states that the prejudiced behaviour that children display in middle childhood, as well as the change that occurs during that period, can be explained by the cognitive capacities pertinent to each of the child's developmental stages (Aboud, 1988; Bigler \& Liben, 1993; Doyle \& Aboud, 1995). In Aboud's view, several concrete operational capabilities that emerge in middle childhood, namely conservation, reconciliation of different perspectives, multiple classification, and attention to individual differences within groups contribute to break down children's over-use of exaggerated homogenous characteristics and thus to reduce prejudice (Aboud \& Amato, 2001). Consistent with the cognitive-developmental theory (CDT), there is some evidence that White children in late 
childhood show fewer negative attitudes toward other groups than younger children do (Aboud \& Skerry, 1984; Doyle, Beaudet, \& Aboud, 1988; for a review, see Aboud, 2005).

Inconsistent with the CDT, however, other research has shown that the developmental sequence described by the theory can hardly account for children's development of intergroup bias. Specifically, a number of studies have shown that beyond 6 or 7 years, as well as through the period of adolescence, White children and youngsters continue to display intergroup bias (e.g., Abrams, 1989; Katz, Sohn, \& Zalk, 1975; Lawrence, 1991; Rutland, 1999). For instance, Katz et al., using a sample of sixth-grade White American children, found no age differences on subtle indicators of intergroup bias against their Black colleagues. They also found a decline in children's negative assessment scores in which elements of social desirability were obvious. Furthermore, Lawrence reported that White American children aged 6 to 9 years interpreted pictures depicting ambiguous situations involving two White children more positively than the same ambiguous pictures involving two Black children. Using similar ambiguous situation tasks, McGlothlin, Killen, and Edmonds (2005) also found implicit intergroup bias in White American children aged 6-7 and 9-10 years old.

In order to shed light on these contradictory results, more recent research within the socionormative approach (Crandall, Eshleman, \& O'Brien, 2002; Milner, 1996; Rutland, 2004; Sechrist, Stangor, \& Killen, 2005; Sherif, 1936) has explored the role of norm awareness and normative pressure on White children's expressions of intergroup bias and intergroup-biased behaviour. According to this approach, as they grow older, White children would be more strongly constrained by parents, teachers, and society in general to comply with the prevailing anti-racist norm, namely in public situations, while keeping more or less private prejudiced beliefs and feelings that result from the dominant influences of their more significant in-groups (Sherif, 1936).

In support of this approach, Killen, Lee-Kim, McGlothlin, and Stangor (2002) have shown that both younger and older White children were aware of the anti-racist norm that prevents blatant expressions of prejudiced behaviour. Furthermore, Rutland, Cameron, Milne, and McGeorge (2005) have shown that both younger and older White children aged less than 10 years could be externally motivated to control their prejudiced behaviour under high public self-focus, while they simultaneously showed implicit intergroup bias. According to these authors, because of the process of norm internalization that would occur in middle childhood (Abrams, Rutland, \& Cameron, 2003; Ruble, Alvarez, Bachman, \& Cameron, 2004), and due to self-presentation concerns (Banerjee, 2002; Katz et al., 1975; Lawrence, 1991; Levy \& Troise, 2001), older children's public behaviour actually seems to become less biased. In the same vein, França and Monteiro (2004) manipulated normative salience using the experimenter's presence (high salience) versus absence (low salience) during a task involving money allocation to an in-group (White) and an out-group (Black) target. Younger children displayed intergroup bias in both conditions while older children only expressed bias in the low salience condition. The authors concluded that, for the older children, the presence of the interviewer created a normative context where intergroup bias was the undesirable behaviour. For the younger children, however, this normative context was not sufficient to influence their consistent pro ingroup bias.

The inhibiting effect of the presence of an experimenter on the expression of anti-normative behaviour has already been observed in a number of studies. Specifically, 8- to 9-year-old girls were found to display significantly less anti-normative aggressive behaviour in the presence of an experimenter than in their absence (Lipscomb, 1972), and White research participants' reduced racial bias in Internet-based studies was found to be due to the presence of the experimenter rather than to conducting the experiment on the laboratory environment (Evans, Garcia, Garcia, \& Baron, 2003). Additionally, Rutland et al. (2005) showed that when children were under a high public self-focus condition, they expressed less intergroup bias.

However, to our knowledge no study examining the development of ethnic intergroup bias has either manipulated normative pressure as the presence vs absence of the experimenter or has explicitly activated the anti-racist vs racist norms. Accordingly, in Study 1 we hypothesized that 6- to 7 -year-old children would display in-group bias regardless of the presence or absence of the experimenter, whereas 9- to 10-year-old children would display the same in-group bias only when the experimenter was absent. In Study 2 it was expected that younger children's intergroup bias would not be changed by the activation of the racist or anti-racist norms whereas older children 
would comply with the norm orientation provided by both manipulations.

\section{STUDY 1}

\section{Method}

\section{Participants and design}

Participants were 283 White Portuguese children (125 first graders, aged 6-7 years; 54.2\% female; and 158 fourth graders, aged 9-10 years, 53.8\% female) attending 15 primary schools of mixed ethnicity (30-40\% Black; 60-70\% White) in the suburban area of Lisbon. All children were primarily from working-class backgrounds and all were given parental permission to participate in the study.

The design was a 2 (age: 6-7, 9-10) $\times 2$ (interviewer: present, absent) between-subject factorial plan with intergroup bias as the dependent variable.

\section{Procedure}

In order to replicate França and Monteiro's (2004) study with White Brazilian children, the same procedure was adopted. Each child was individually interviewed at school by a White female interviewer. The interviewer's presence was believed to make the anti-racist norm salient. Conversely, her absence was believed to create a favourable context for children's intergroupbiased behaviour to be expressed.

The experimental task followed a helping paradigm. Children were asked to distribute nine 1 Euro-coins to two same-sex (White and Black) target children and to put them into two allegedly locked money-boxes on which the target children's photos were attached. In the interviewer-absence condition, the interviewer also told the child to keep doing the task while she left the room to drink some water.

\section{Measures}

Dependent variable. An intergroup bias index was computed by subtracting the money given to the Black child from the money given to the White child $(-9=$ maximum out-group favouritism; $+9=$ maximum in-group favouritism).

The content of the anti-racist norm. In order to identify children's justifications for their reported in-group or out-group favouring behaviour, as well as the allocation behaviour they expected from one of their caretakers, in a subsample of 201 children (101 aged 6-7 years; 50.5\% female; and 100 aged $9-10$ years, 55\% female; 102 previously assigned to the "interviewer present" condition; 99 assigned to the "interviewer absent" condition), the interviewer proceeded with the following questions after the money allocation task: "How much money did you give to each child? Why?" and "How much money would your father (mother, other caretaker) give to each child? Why?" Children's exact answers were recorded, regardless of their actual previous allocation behaviour.

\section{Results}

Intergroup bias. In order to test our hypotheses, a 2 (age: 6-7, 9-10) × 2 (sex: male, female) $\times 2$ (interviewer: present, absent) ANOVA was performed with the intergroup bias index as dependent variable. As there were no main or interaction effects involving sex, data were collapsed across this variable in further analyses.

ANOVA results revealed a main effect for Age, $F(1,282)=5.81, p<.05, \eta^{2}=.02$, indicating that younger children displayed more intergroup bias $(M=0.46, S D=1.29)$ than older children $(M=$ $0.09, S D=1.27)$. This effect was qualified by the Age $\times$ Interviewer interaction (see Figure 1), $F(1,282)=4.18, p<.05, \eta^{2}=.02$, indicating that younger children's intergroup bias did not depend on interviewer's presence vs absence, $F(1,124)=$ $0.56, n s$ (interviewer present: $M=0.55, S D=1.35$; interviewer absent: $M=0.37, S D=1.22$ ), whereas in older children it did, $F(1,157)=5.07, p<.05$ (interviewer present: $M=-0.13, S D=1.15$; interviewer absent: $M=0.32, S D=1.34$ ). Moreover, $t$-tests of means against the scale midpoint (0) showed that younger children displayed intergroup bias in both conditions:

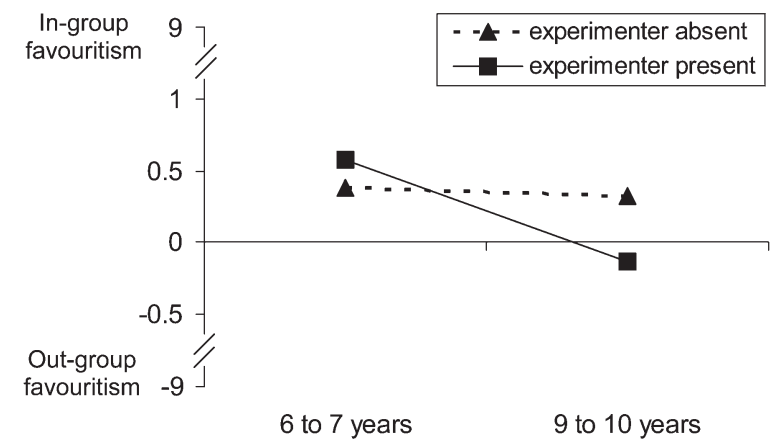

Figure 1. Children's intergroup bias by age and interviewer conditions. 
interviewer present: $t(65)=3.28, p<.01$; interviewer absent: $t(58)=2.36, p<.05$. Older children, however, only favoured the in-group in the interviewer absent condition: interviewer absent: $t(81)=2.14, p<.05$; interviewer present: $t(75)=$ $-1.00, n s$.

The content of the anti-racist norm. A content analysis was performed on the explanations children gave to their own and their caretakers' expected intergroup behaviour. This analysis provided three main response categories, largely independent of age and subject (own/caretaker), accounting for $56 \%$ of the total answers for ownbehaviour justifications and for $54 \%$ of the total answers for caretaker's expected behaviour justifications. The three justifications were "perceived similarity" ("because he/she looks like me"), "blatant racism" (because I don't like him/herthe Black target) and "merit" ("because he/she deserved it more"). To test whether the distribution of the observed frequencies, within each agegroup, was consistent with an association between children's reported allocation behaviour and their justifications for that behaviour, a Chi-square was computed for each age-group. Children's justifications were associated with their reported intergroup allocation behaviour for both $6-7, \chi^{2}(8, N$ $=101)=29.17, p<.001$, and $9-10$ years old, $\chi^{2}(8$, $N=100)=37.77, p<.001$.

To interpret this association, the cells with adjusted standardized residuals above 2 (i.e., observed frequency higher than expected) and below -2 (i.e., observed frequency lower than expected) were analysed. Results showed that for both age groups, in-group favouring behaviour was consistently justified by blatant racism, while out-group favouring behaviour was attributed to a merit-based understanding of the situation. Moreover, younger children who reported favouring the in-group did not use the merit justification, and those who reported favouring the out-group did not use the similarity and blatant racism justifications. As the younger age group, older children who reported favouring the out-group did not utilize the blatant racism justification (see Table 1).

Chi-square tests indicated that children's justifications for caretaker's expected behaviour were, irrespective of age, significantly related to whether they expected their caretaker to favour the ingroup or the out-group: $6-7$ years old, $\chi^{2}(8, N=$ $101)=57.95, p<.001 ; 9-10$ years old, $\chi^{2}(8, N=$ $100)=114.27, p<.001$. Specifically, the results revealed that expected in-group favouring behaviour was mainly justified by similarity and blatant racism explanations, but not by merit (see Table 2). Consistent with findings regarding ownbehaviour justifications, both younger and older children primarily explained their caretakers' outgroup favouring behaviour in terms of merit, and not by similarity or blatant racism.

\section{Discussion}

The results of this study showed that whereas younger children were not sensitive to the presence of the White interviewer as a cue for activating the anti-racist norm, older children seemed to selfregulate their behaviour according to that cue, by only displaying a biased behaviour against the black child when the experimenter was absent. Accordingly we can conclude that children's age is important, not because intergroup bias declines with age, as stated by CDT, but because with age expression of bias can be better self-monitored

TABLE 1

Frequencies of participants' justifications for reported resource allocation behaviour

\begin{tabular}{|c|c|c|c|c|c|c|}
\hline \multirow[b]{3}{*}{ Justifications } & \multicolumn{3}{|c|}{$6-7$ years old } & \multicolumn{3}{|c|}{ 9-10 years old } \\
\hline & \multicolumn{3}{|c|}{ Reported allocation behaviour } & \multicolumn{3}{|c|}{ Reported allocation behaviour } \\
\hline & $\begin{array}{l}\text { Favoured } \\
\text { in-group }\end{array}$ & $\begin{array}{l}\text { Favoured } \\
\text { out-group }\end{array}$ & $\begin{array}{l}\text { Don't know/ } \\
\text { Nonsense }\end{array}$ & $\begin{array}{l}\text { Favoured } \\
\text { in-group }\end{array}$ & $\begin{array}{l}\text { Favoured } \\
\text { out-group }\end{array}$ & $\begin{array}{c}\text { Don't know/ } \\
\text { Nonsense }\end{array}$ \\
\hline Similarity & 9 & $2(-)$ & $10(+)$ & 2 & 1 & 0 \\
\hline Blatant racism & $14(+)$ & $1(-)$ & 4 & $5(+)$ & $0(-)$ & 0 \\
\hline Merit & $4(-)$ & $12(++)$ & 2 & 9 & $37(+)$ & 0 \\
\hline Other & 5 & 5 & 3 & 5 & 13 & 5 \\
\hline $\begin{array}{l}\text { Doesn't answer/ } \\
\text { Doesn't know }\end{array}$ & 17 & 8 & 5 & 5 & 10 & $8(+)$ \\
\hline Total & 49 & 28 & 24 & 26 & 61 & 13 \\
\hline
\end{tabular}

+ indicates that an adjusted standardized residual (asr) above 2 was observed, meaning that the observed frequency for that cell was above its expected frequency; ++ asr $>4$. - indicates that an asr below 2 was obtained, meaning that the observed frequency for that cell was below its expected frequency. 
TABLE 2

Frequencies of participants' justifications for expected parents' resource allocation behaviour

\begin{tabular}{|c|c|c|c|c|c|c|}
\hline \multirow[b]{3}{*}{ Justifications } & \multicolumn{3}{|c|}{ 6-7 years old } & \multicolumn{3}{|c|}{ 9-10 years old } \\
\hline & \multicolumn{3}{|c|}{ Expected allocation behaviour } & \multicolumn{3}{|c|}{ Expected allocation behaviour } \\
\hline & $\begin{array}{l}\text { Favoured } \\
\text { in-group }\end{array}$ & $\begin{array}{l}\text { Favoured } \\
\text { out-group }\end{array}$ & $\begin{array}{l}\text { Doesn't know/ } \\
\text { Nonsense }\end{array}$ & Favoured in-group & $\begin{array}{l}\text { Favoured } \\
\text { out-group }\end{array}$ & $\begin{array}{c}\text { Doesn't know/ } \\
\text { Nonsense }\end{array}$ \\
\hline Similarity & $12(+)$ & $1(-)$ & 5 & $8(++)$ & $1(-)$ & 0 \\
\hline Blatant racism & $10(+)$ & $1(-)$ & 2 & $7(++)$ & $1(-)$ & 0 \\
\hline Merit & $1(-)$ & $16(+++)$ & $1(-)$ & $4(-)$ & $45(+++)$ & $0(--)$ \\
\hline Other & 4 & 3 & 7 & 6 & 6 & 1 \\
\hline $\begin{array}{l}\text { Doesn't answer/ } \\
\text { Doesn't know }\end{array}$ & 14 & $5(-)$ & $19(+)$ & $1(-)$ & $4(-)$ & $16(+++)$ \\
\hline Total & 41 & 26 & 34 & 26 & 57 & 17 \\
\hline
\end{tabular}

+ indicates that an adjusted standardized residual (asr) above 2 was observed, meaning that the observed frequency for that cell was above its expected frequency; ++ asr $>4 ;+++$ asr $>6$. - indicates that an asr below 2 was obtained, meaning that the observed frequency for that cell was below its expected frequency; $-\quad-$ asr $<4$.

according to different levels of normative pressure present in the context.

Consistent with Killen and colleagues' work (2002), the second relevant finding of this study was that children used different justifications for their and others' in-group and out-group favouring behaviours: Blatant racism and perceived similarity with the in-group target were the prevalent basis for justifying in-group favouring behaviour, while the merit motive seemed to underlie out-group favouritism. Thus, in a second study these norms were directly manipulated as cues for children's behaviour (instead of the presence/absence of the experimenter). It was expected that younger children's intergroup bias would not be changed by the activation of these norms whereas older children would comply with the norm orientation provided by the manipulations.

\section{STUDY 2}

\section{Method}

\section{Participants and design}

One hundred and eighty-seven White Portuguese children (91 first-graders aged 6-7 years, $51.6 \%$ female; 96 fourth graders aged 910 years, $56.3 \%$ female) participated in this study. Children attended 12 primary schools of mixed ethnicity (30-40\% Black Portuguese, $60-70 \%$ White Portuguese) in the suburban area of Lisbon. The children were from primarily working-class backgrounds and all were given parental permission to participate in the study.
The experimental design was a 2 (age: 6-7, 9-10) $\times 2$ (activated norm: anti-racist, racist) $\times 3$ (norm type: similarity-nationality, similarity-humanity, merit) between-subject factorial plan, again with intergroup bias as the dependent variable.

\section{Procedure}

Each child was individually interviewed at school by a White female interviewer. The interviewer gave the child the same instructions as described in Study 1 regarding the task of allocating money to the two target children. Before allowing the child to start the task the experimenter introduced the norm manipulations. The norm of similarity was operationalized in two ways: nationality-based similarity (Blacks and Whites are Portuguese) and humanity-based similarity (Blacks and Whites are persons). The norm of merit was operationalized with the assumption of ethnic asymmetry (White persons earn more money than Black persons but both deserve the same). In the three norm-type conditions an antiracist norm versus a racist norm was also manipulated. In all conditions the interviewer first told the child: "In Portugal there are many whiteskinned persons and there are others with a darker skin. One group is called the Whites and the other is the Blacks."

Then the interviewer proceeded with the antiracist/racist (in brackets) norm manipulation. In the nationality-based condition, she said: "But their skin colour doesn't matter, as they all live and work in Portugal and all are Portuguese (But their skin colour is very important, as it shows that White persons are Portuguese and Black persons are not). And that is how it must be". In the 
humanity-based condition, the interviewer told the child: "(...) but their skin colour doesn't matter. White persons are very similar to Black persons because they are all human beings (But their skin colour is very important. White persons are very different from Black persons and we prefer people who are more similar to us). And that is how it must be". In the merit-based condition, after the first statement, the interviewer told the child: "(...) White persons have better houses and more toys for their children because they earn more money than Black persons. But both deserve the same things because they both work hard and need the money to live well (But they do not deserve the same things because those who work harder must take home more money). And that is how it must be".

After checking for the child's correct understanding of the manipulation content, the experimenter asked him/her to perform the money allocation task (for the procedure see Study 1), during which she turned her back to the child. This procedure was designed to control for the experimenter's presence effect.

Before leaving, children were thanked and debriefed. Special debriefing procedures were run in order to counteract the potential negative effects of the racist manipulations. Children in this experimental condition were invited to comment on what they had been told and the conversation proceeded until the child by himself refused the racist assumptions.

\section{Measures}

Manipulation checks. After the allocation task the manipulation checks for the effect of the antiracist/racist norms were introduced. Children were asked three filler questions and two specific check questions, one racist and one anti-racist, modified according to the type of manipulated norm. The manipulation checks for the racist norm were as follows: "White persons are Portuguese and Black persons are not" (similarity-nationality); "We prefer people who are more similar to us" (similarity-humanity) and "Those who work harder must earn more money" (merit). The antiracist manipulation checks were as follows: "Both Black and White people are Portuguese" (similarity-nationality); "Both Blacks and Whites are human beings" (similarity-humanity), and "Both Whites and Blacks work hard and deserve money to live well" (merit). Children answered the five statements on a 3-point ladder scale $(1=I$ think it is not at all true to $3=I$ think it is true).
Dependent variable. An intergroup bias index was computed in the same way as in Study 1.

\section{Results}

Preliminary analyses. Exploratory data analyses were performed on the children's bias index $(-9$ to +9$)$ to make sure that it met the distributional requirements of the ANOVA. Data were also examined for sex effects. As sex did not reveal any main or interaction effects, data were collapsed across sexes in further analyses.

Manipulation check. Responses to the manipulation check questions were analysed in a 2 (age: 6-7 vs. 9-10 years old) $\times 2$ (activated norm: racist, anti-racist) $\times 3$ (norm type: similarity-nationality, similarity-humanity, merit) $\times 2$ (type of check question: anti-racist, racist) MANOVA with the last factor within participants. The anti-racist check question was reversed so that the scale interpretation could be consistent with the racist check question. Accordingly, higher values on both racist and anti-racist check questions indicate that children respectively agreed more with the racist and less with the anti-racist check questions.

The results revealed a main effect of Age, $F(1$, $175)=4.26, p<.05, \eta^{2}=.02$, indicating that older children agreed with the racist (and disagreed with the anti-racist) check questions, (9-10 years old: $M$ $=1.73, S D=0.47)$ significantly less than younger children (6-7 years-old: $M=1.91, S D=0.50)$. Moreover, a main effect of Activated Norm was also found, $F(1,175)=8.05, p<.01, \eta^{2}=.04$, showing that the norm activation (racist vs antiracist) was successful. Specifically, participants in the racist norm activated condition agreed more with the check questions $(M=1.91, S D=0.47)$ than participants assigned to the anti-racist norm activated condition, $(M=1.72, S D=0.50)$. Finally, an interaction effect of Age $\times$ Activated Norm was also found, $F(1,175)=9.04, p<.01, \eta^{2}$ $=.05$. The analysis of simple effects within each age group indicated that for younger participants the activated norm manipulation did not affect children's responses on the check questions, $F(1$, $90)=0.09, n s, \eta^{2}=.00$, with these being equal to the scale midpoint on both conditions: racist $(M=$ $1.92, S D=0.48), t(44)=-1.10, n s ;$ anti-racist $(M$ $=1.89, S D=0.53), t(45)=-1.40, n s$; for older ones the expected significant effect was found, $F(1$, $95)=15.62, p<.01, \eta^{2}=.14$. Older participants in the racist activated norm condition agreed with check questions significantly more than those on 


\section{MONTEIRO, DE FRANÇA, RODRIGUES}

the anti-racist activated norm condition: racist ( $M$ $=1.91, S D=0.46), t(45)=-1.27, n s$; anti-racist $(M=1.56, S D=0.41), t(49)=-7.55, p<.001$.

Intergroup bias. Results revealed a significant effect of Age, $F(1,186)=14.49, p<.001, \eta^{2}=.08$. As predicted, younger participants $(M=0.47, S D$ $=1.29)$ were more biased than older participants $(M=-0.29, S D=1.15)$. According to our main hypothesis the age effect was qualified by an Age $\times$ Activated Norm interaction effect, $F(1,187)=$ $4.09, p<.05, \eta^{2}=.02$. Simple main effect analyses revealed that younger children exhibited intergroup bias regardless of the norm condition, $F(1$, $90)=0.49, n s, \eta^{2}=.01$; racist $(M=0.37, S D=$ $1.44), t(45)=2.90, p<.05$; anti-racist $(M=0.57$, $S D=1.07), t(45)=3.03, p<.01$. In contrast, older children were affected by the norm manipulation, $F(1,95)=4.20, p<.05, \eta^{2}=.04$, even displaying out-group favouritism in the anti-racist norm condition $(M=-0.56, S D=1.01), t(49)=$ $-3.91, p<.001$. Differently from the hypothesis, in the racist norm condition older children did not display intergroup bias $(M=-0.09, S D=1.24)$, $t(46)=-0.47, n s$.

Besides, a main effect for the Norm type was also present, $F(2,187)=3.17, p<.05, \eta^{2}=.04$. Comparison of the cell means using Duncan's multiple range test revealed that participants' ingroup bias in the similarity-humanity norm $(M=$ $0.45, S D=0.90)$ was higher than in the similaritynationality $(M=-0.08, S D=1.53)$ condition, and in the merit norm condition $(M=-0.11, S D$ $=1.26$ ). In fact, only in the similarity-humanity condition did the mean index score differ from zero, $t(39)=3.15, p<.05$. Considering that only in the similarity-humanity condition children displayed a biased behaviour, a further ANOVA of 2 (age) $\times 2$ (activated norm) for that condition $(n$ $=40 ; 52.5 \%$ female) was carried out on the bias index.

Results showed a main effect of Age, $F(1,39)=$ $17.78, p<.001, \eta^{2}=.33$, meaning that younger children were more biased $(M=0.90 ; S D=0.45)$ than older ones $(M=0.00 ; S D=1.03)$. A main effect of Activated Norm in the expected direction was also found, $F(1,39)=10.76, p<.01, \eta^{2}=.23$, showing that children were only biased in the racist norm condition $(M=0.80 ; S D=0.62)$, since in the anti-racist norm condition they did not express bias $(M=0.10, S D=1.02)$. More important, the expected Age $\times$ Norm interaction effect, $F(1,39)=5.48, p<.05, \eta^{2}=.13$, was also found (see Figure 2). Simple main effects analyses showed that younger children exhibited a biased behaviour regardless of the norm condition, $F(1$,

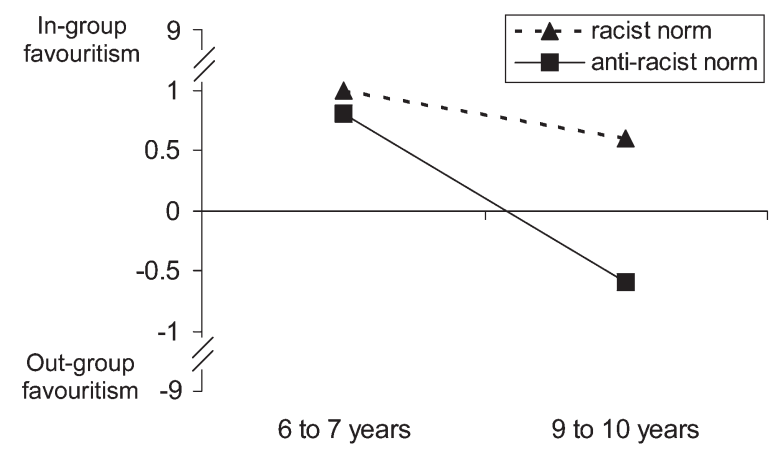

Figure 2. Children's intergroup bias by age and norm activation in the similarity-humanity condition.

$19)=1.00, n s, \eta^{2}=.05:$ racist $(M=1.00, S D=$ $0.00), t(9)=3.90, p<.001$; anti-racist $(M=0.80$, $S D=0.63), t(9)=3.30, p<.01$. Older children, however, complied both with the anti-racist norm [even presenting out-group favouritism, $F(1,19)=$ 10.13, $\left.p<.01, \eta^{2}=.36\right](M=-0.60, S D=0.84)$, $t(9)=-2.25, p<.05$, and with the racist norm $(M=0.60, S D=0.84), t(9)=2.25, p<.05$, by displaying clear intergroup bias.

\section{Discussion}

In this study the two norms that most children had used in Study 1 to explain their own/ caretaker money allocation behaviour to the Black and White target children were manipulated: perceived intergroup similarity vs dissimilarity and intergroup merit vs equality. Overall, the main findings were consistent with the hypotheses: Whereas younger children exhibited a biased behaviour regardless of the activation of anti-racist or racist norms (Aboud, 1988; Nesdale, Maass, Durkin, \& Griffiths, 2005), older children complied with the anti-racist, but not with the racist, norm. Considering that a main effect for the type of norm indicated that, in fact, children's biased behaviour was only biased in the similarity-humanity condition, a separate treatment of that condition allowed a more clear-cut picture of results: Older children's behaviour was in line with the intergroup similarity norm (both in the racist and in the anti-racist conditions) whereas, again, younger children consistently displayed a biased behaviour, regardless of the racist or anti-racist nature of the activated norm. This result seems to underline the fact that different norms can have different effects on the regulation of older children's behaviour, particularly when norms that facilitate the expression of intergroup bias are used. 


\section{GENERAL DISCUSSION}

The present research examined the effect of social norms on the expression or suppression of White children's intergroup biased behaviours in two age groups. Norm pressure was manipulated either by the presence or absence of the experimenter during the children's performance of the task (Study 1) or by the verbal activation of anti-racist vs racist norms (Study 2). In line with the hypotheses, we found that both the experimenter's presence and the activation of an interracial similarity norm did not affect younger children's intergroup bias but suppressed older children's biased behaviour. Contrary to the internalization hypothesis (Rutland et al., 2005), older children also displayed bias when the amount of normative pressure was significantly reduced, either by removing the interviewer or by activating a discrimination norm. Moreover, the fact that Study 2 replicated the results of Study 1 is important, as it shows that the mere presence of an in-group adult (Study 1) can be as powerful as a direct verbal activation of a norm (Study 2) to either legitimate or prohibit older children's expression of intergroup bias.

Besides assessing children's intergroup behaviour, we intended to uncover the normative explanations underlying their reported behaviours and the expected behaviours of their caretakers. Results showed that in-group favouring behaviour was primarily explained by perceptions of similarity between self and the in-group target child and, interestingly, that the use of this explanation didn't decrease with age, as it would be expected by the cognitivedevelopmental theory (Doyle \& Aboud, 1995). Moreover, a significant percentage justified their bias in terms of disliking the out-group member or the out-group as a whole. This result suggests that intergroup bias may be closer to intergroup prejudice than was initially assumed (Rutland, 2004), and supports the idea that the focus of children's racial attitudes (in-group vs outgroup) is probably more status- and contextrelated than development-dependent. Finally, reported and expected out-group favouring behaviours were consistently explained through the merit of the out-group target child. The merit motive has been found to be a pervasive source of subtle in-group favouritism rather than one for out-group favouritism in White young adults (e.g., Lima \& Vala, 2002). Its use by White children suggests that they are aware of its positive social meaning. More important, preferring this external motive to the more internal similarity motive suggests that subtle prejudice can also be at work in this situation.

How do White children handle such contradictory norms in their daily lives? Some authors suggest that the developmental path of prejudice may be better understood if the importance of children's ability to self-regulate their expression of intergroup bias is acknowledged (Rutland, 2004). We suggest that this ability can account for children's compliance with different social norms according to the normative meaning and pressure that are fuelled into the behavioural contexts. We also suggest that the most stable and active norms regarding interethnic behaviour for both age-groups are intergroup distinctiveness and in-group favouring (Nesdale, 2004; Tajfel, 1982). However, while older children concurrently face the opposite and equally strong norm that prohibits the interethnic bias and can manage the hierarchical use of both norms (Kohlberg, 1963) according to context normative and self-presentation demands, younger children are less able to do this. Thus, although younger children are aware of the anti-racism norm, a substantial normative pressure would be needed for them to skip the in-group favouring norm and comply with the anti-racism one (Rutland et al., 2005). In sum, the current research ascertains that White children's expressions of intergroup bias toward stigmatized groups become polymorphic in middle childhood, by showing that different intergroup behaviours can occur through a selective use of concurrent norms according to context demands.

The present research can be appreciably expanded in future studies if some of its limitations are acknowledged, namely, the potential confound between in-group bias and out-group negativity of our zero-sum measure of intergroup bias. Using a different measure should allow a clear picture of which norms are promoting in-group favouritism and which ones are fostering out-group prejudice.

The finding that older children's expressions of intergroup bias are more context-dependent than those of younger children can have important educational consequences: If children of dominant social groups do not automatically reduce intergroup biased behaviours with age, as predicted by cognitive-developmental theory, stronger anti-racist norms as well as more normative contexts may be needed (Verkuyten \& Thijs, 2002) to help older children abide by minorities' social rights. 


\section{REFERENCES}

Aboud, F. E. (1988). Children and prejudice. Oxford, UK: Basil Blackwell.

Aboud, F. E. (2005). The development of prejudice in childhood and adolescence. In J. F. Dovidio, P. Glick, \& L. Rudman (Eds.), On the nature of prejudice (pp. 310-326). Oxford, UK: Blackwell.

Aboud, F. E., \& Amato, M. (2001). Developmental and socialization influences on intergroup bias. In $\mathrm{R}$. Brown \& S. L. Gaertner (Eds.), Blackwell handbook of social psychology, Vol. 4. Intergroup relations (pp. 65-85). Oxford, UK: Blackwell.

Aboud, F. E., \& Skerry, S. (1984). The development of ethnic attitudes. Journal of Cross-Cultural Psychology, 15, 3-34.

Abrams, D. (1989). Differential association: Social developments in gender identification during adolescence. In S. Skevington \& D. Baker (Eds.), The social identity of women (pp. 59-83). London: Sage.

Abrams, D., Rutland, A., \& Cameron, L. (2003). The development of subjective group dynamics: Children's judgments of normative and deviant ingroup and out-group individuals. Child Development, $74,1840-1856$

Banerjee, R. (2002). Audience effects on self-presentation in childhood. Social Development, 11, 487-507.

Biernat, M., Vescio, T. K., Theno, S. A., \& Crandall, C. S. (1996). Values and prejudice: Toward understanding the impact of American values on outgroup attitudes. In C. Seligman, J. M. Olson, \& M. P. Zanna (Eds.), The psychology of values: The Ontario Symposium, Vol. 8 (pp. 153-189). Mahwah, NJ: Lawrence Erlbaum Associates Inc.

Bigler, R. S., \& Liben, L. S. (1993). A cognitive developmental approach to racial stereotyping and reconstructive memory in Euro-American children. Child Development, 64, 1507-1518.

Crandall, C. S., Eshleman, A., \& O'Brien, L. (2002). Social norms and the expression and suppression of prejudice the struggle for internalization. Journal of Personality and Social Psychology, 82, 359-378.

Dovidio, J. F., Kawakami, K., \& Beach, K. R. (2001). Implicit and explicit attitudes: Examination of the relationship between measures of intergroup bias. In R. Brown \& S. L. Gaertner (Eds.), Blackwell handbook of social psychology: Vol. 4. Intergroup relations (pp. 175-197). Oxford, UK: Blackwell.

Doyle, A. B., \& Aboud, F. E. (1995). A longitudinal study of white children's racial prejudice as a socialcognitive development. Merrill-Palmer Quarterly, 41, 210-229.

Doyle, A. B., Beaudet, J., \& Aboud, F. E. (1988). Developmental changes in the flexibility of children's ethnic attitudes. Journal of Cross-Cultural Psychology, 19, 3-18.

Evans, D. C., Garcia, D. J., Garcia, D. M., \& Baron, R. S. (2003). In the privacy of their own homes: Using the internet to assess racial bias. Personality and Social Psychology Bulletin, 29, 273-284.

França, D. X., \& Monteiro, M. B. (2001, July). Old and new racisms: Intergroup discrimination in Black, Brown and White Brazilian children. Paper presented at the VII ${ }^{\text {th }}$ European Congress of Psychology, London, UK.
França, D. X., \& Monteiro, M. B. (2004). The indirect expression of racism in childhood. Psicologia, 4, 705-720.

Gaertner, S. L., \& Dovidio, J. F. (1986). The aversive form of racism. In J. F. Dovidio \& S. L. Gaertner (Eds.), Prejudice, discrimination, and racism: Theory and research (pp.61-89). Orlando, FL: Academic Press.

Katz, P. A., Sohn, M., \& Zalk, S. R. (1975). Perceptual concomitants of racial attitudes in urban gradeschool children. Developmental Psychology, 11, 135-144.

Killen, M., Lee-Kim, J., McGlothlin, H., \& Stangor, C. (2002). How children and adolescents evaluate gender and racial exclusion. Monographs for the Society for Research in Child Development (Serial No. 271, Vol. 67, No. 4). Oxford, UK: Blackwell.

Kohlberg, L. (1963). Development of children's orientations toward a moral order. Vita Humana, 6, 11-36.

Lawrence, V. W. (1991). Effect of socially ambiguous information on White and Black children's behavioural and trait perceptions. Merrill-Palmer Quarterly, 37, 619-630.

Levy, S. R., \& Troise, D. M. (2001, April). Children's social concerns with appearing prejudiced. In $\mathrm{C}$ McKown, Chair, The development and consequences of stereotype processes in childhood. Paper presented at the Biennial Meeting of the Society for Research in Child Development, Minneapolis, MN, USA.

Lima, M., \& Vala, J. (2002). Individualismo meritocrático, diferenciação cultural e racismo [Meritocratic individualism, cultural differentiation and racism]. Análise Social, 37, 181-207.

Lipscomb, T. R. (1972). The effects of experimenter presence and absence and physical or nonphysical means of expression on sex differences in aggression. Unpublished master's thesis, San Francisco State University, San Francisco, USA.

McGlothlin, H., Killen, M., \& Edmonds, C. (2005). European-American children's intergroup attitudes about peer relationships. British Journal of Developmental Psychology, 23, 227-249.

Milner, D. (1983). Children and race: Ten years on. London: Ward Lock Educational.

Milner, D. (1996). Children and racism: Beyond the value of the dolls. In W. P. Robinson (Ed.), Social groups and identities. Developing the legacy of Henri Tajfel (pp. 246-268). Oxford, UK: Butterworth.

Nesdale, D. (2001). Development of prejudice in children. In M. Augoustinos \& K. Reynolds (Eds.), Understanding prejudice, racism and social conflict (pp. 57-73). London: Sage.

Nesdale, D. (2004). Social identity processes and children's ethnic prejudice. In M. Bennett \& F. Sani (Eds.), The development of social self (pp.219-246). Hove, UK: Psychology Press.

Nesdale, D., Maass, A., Durkin, K., \& Griffiths, J. (2005). Group norms, threat and children's racial prejudice. Child Development, 76, 652-663.

Pettigrew, T. F., \& Meertens, R. W. (1995). Subtle and blatant prejudice in Western Europe. European Journal of Social Psychology, 25, 57-75.

Quintana, S. M. (1988). Children's developmental understanding of ethnicity and race. Applied and Preventive Psychology, 7, 27-45.

Rodrigues, R., Monteiro, M. B., \& Rutland, A. (2006, September). The cognitive and socio-normative 
development of ethnic intergroup attitudes during childhood: Integrating different theoretical approaches. Paper presented at the 53rd British Psychological Society Annual Conference, Social Psychology Section, Birmingham, UK.

Ruble, D. N., Alvarez, J., Bachman, M., \& Cameron, J. (2004). The development of a sense of "we": The emergence and implications of children's collective identity. In M. Bennett \& F. Sani (Eds.), The development of social self (pp.29-76). Hove, UK: Psychology Press.

Rutland, A. (1999). The development of national prejudice, in-group favouritism and self-stereotypes in British children. British Journal of Social Psychology, 38, 55-70.

Rutland, A. (2004). The development and self-regulation of intergroup attitudes in children. In M. Bennett \& F. Sani (Eds.), The development of social self (pp. 247-266). Hove, UK: Psychology Press.
Rutland, A., Cameron, L., Milne, A., \& McGeorge, P. (2005). Social norms and self-presentation: Children's implicit and explicit attitudes. Child Development, 762, 451-466.

Sechrist, G. B., Stangor, C., \& Killen, M. (2005). Stereotypes and prejudice as social norms. In C. S. Crandall \& M. Schaller (Eds.), The social psychology of prejudice: Historical perspectives (pp.163-183). Seattle, WA: Lewinian Press.

Sherif, M. (1936). The psychology of social norms. New York: Harper's.

Tajfel, H. (1982). Social psychology of intergroup relations. Annual Review of Psychology, 33, 1-39.

Verkuyten, M., \& Thijs, J. (2002). Racist victimization among children in the Netherlands: The effect of ethnic group and school ethnic composition. Ethnic and Racial Studies, 25, 310-331. 